\title{
REORGANIZING THE FEDERAL EXECUTIVE BRANCH: THE LIMITS OF INSTITUTIONALIZATION*
}

\author{
Harvey C. Mansfield $\dagger$
}

\section{INTRODUCTION}

Reorganization, in the broad sense, is one of the instruments for managing social change. Managing change in the structure of government is a political operation. Reorganization in the federal executive branch, on a scale or at a level that attracts external notice, is accordingly a process caught up in the stresses of rivalry between the President and his entourage, the bureaucracy, the Congress and its committees, and organized outside forces, for the control of governmental offices and operations -for whatever uses that control may be put to. It is a process that has been undertaken on a comprehensive scale at least spasmodically ever since $188 \%$, and more systematically during the past twenty or thirty years. Numerous approaches have been tried, sometimes with positive results but often ending in stalemates, at least for the time being.

It is commonly supposed that the Reorganization Act of I939, with its subsequent modifications and extensions, finally succeeded in resolving the earlier impasse by institutionalizing the process-by stating acceptable criteria, by focusing responsibility for the initiative in the form of a Reorganization Plan proposed by the President, and by providing an orderly and assured disposition of it through the expression of congressional acquiescence, implicitly or explicitly, or by the imposition of a congressional veto. There is an element of truth in this but also a considerable exaggeration. The Reorganization Act has indeed introduced an important problem-solving innovation in a sensitive area, but it is far from becoming the standard institutionalized method for accomplishing reorganizations in the executive branch.

I take institutionalizing here to mean the emergence of a patterned response to the need for handling a growing volume of cases involving recurrent issues through specialized agencies that develop an expertise in the subject and, by methods that establish routines, generalize acceptable rules and goals and minimize procedural and personal controversies. ${ }^{1}$ In this sense legislation is an institutionalized process, with limits upon its applicability for various purposes in various circumstances. So is the reorganization plan procedure.

I have dealt in another article with this procedure and with the congressional

\footnotetext{
I am indebted to the Brookings Institution for support in studies of which this is a partial product.

+ Professor of Government, Columbia University.

${ }^{2}$ Cf. Polsby, The Institutionalization of the U.S. House of Representatives, 62 AM. PoL. Scr. REv. I44 (1968).
} 
reception accorded reorganization plans. ${ }^{2} \mathrm{My}$ aim here is to examine how and to what extent the initiative in reorganizations has come to devolve upon the chief executive, and how, among possible alternatives, he has chosen to equip himself with assistance in the formulation of concrete proposals. The first topic calls for a review of leading historical instances of the exercise of the initiative, in the context of shifting objectives from "economy" to program controls by the Congress as well as by the President. The second involves tracing the shift from reliance on public and mixed commissions to unpublicized presidential task forces. From these bodies of evidence some tentative conclusions about the limits of institutionalization may seem warranted. This article is confined to the civilian establishment in the executive branch. Reorganization in the military establishment would, I believe, show analogies; but it would be a separate enterprise to deal with them. ${ }^{3}$

Before coming to the evidence it is appropriate to start briefly with the constitutional sources of difficulty, for the seeds of later contests were planted there. I take it that what the Constitution says, and fails to say, about organization applies also to reorganization.

\section{I}

\section{Constitutional Issues}

The framers of the Constitution took the existence of departments for granted, in two phrases of article II, section 2: "The President ... may require the opinion, in writing, of the principal officer in each of the executive departments upon any subject relating to the duties of their respective offices" and "the Congress may by law vest the appointment of such inferior officers as they think proper ... in the heads of departments." An intervening phrase in the same section speaks, in connection with Senate confirmation, of "all other officers of the United States whose appointments are not herein otherwise provided for, and which shall be established by law ...." The opening sentence of article II vests "the Executive power" in the President and section 2 makes him "Commander-in-Chief of the Army and Navy," but beyond what has already been quoted, and the injunction upon him to "take care that the laws be faithfully executed," no correspondingly explicit language defines his relationships with the civilian establishment. The silences and ambiguities are crucial, for they allowed two contradictory doctrines respecting the unity of the executive branch to take root in 1789 . The issues were exhaustively canvassed in the great debate over the President's removal power in the first Congress; again in connection with the Tenure of Office Act after the Civil War; and still

\footnotetext{
${ }^{2}$ Mansfield, Federal Executive Reorganization: Thirty Years of Experience, 39 Puв. AD. REv. 332 (I969).

${ }^{3}$ For a start, see W. Millis, H. Mansfield, \& H. Stein, Arms and the State 139-85 (I958); S. Huntington, The Soldier and the State (r957); P. Hammond, Organizing for Defense (I96r); D. Caraley, The Politics of Military Unification (1966).
} 
later in the Supreme Court's decisions in the Myers and Humphrey cases. ${ }^{4}$ They are relevant also to reorganization.

It can be plausibly argued that the purpose in assuring the President the written opinions of department heads on request was not only to provide him with informed advice and to make them answerable to him for past actions. It would also enable him to establish clear responsibility before he acted on a pending matter himself or directed the department chief how to act on it-a protection of the principle of hierarchy. George Washington, coming to the Presidency from the Convention, took it so and acted in that fashion. ${ }^{5}$ A President who can direct the exercise of any powers committed to a subordinate can afford to take a relaxed view of the formal structure of the establishment of which he is the pinnacle. In Washington's case the statutes commonly delegated final authority directly to him.

Simultaneously, however, when the Congress established the Treasury Department it fixed the main features of the department's organization by specifying five distinct offices-Secretary, Comptroller, Auditor, Treasurer and Register-and their duties, so arranged as to provide internal safeguards for the integrity of the fiscal transactions of the government, and to bring direct reports from the Secretary to Congress. ${ }^{6}$ This produced no difficulties between Washington and Hamilton, but it set a precedent for what presently became the prevailing practice, in the Igth Century and after, of statutory powers and instructions running to specified officials of or below Cabinet rank, rather than to the President. ${ }^{7}$ Not quite half a century later, Andrew Jackson in 1833 asserted a constitutional prerogative as direct representative of the people to order his Secretary of the Treasury to remove the government's deposits from the Bank of the United States. But he found it necessary to that end first to remove the Secretary, in favor of another more amenable to instruction. And when in the aftermath of that episode the same claim was again made in defense of an action on the part of Jackson's Postmaster General, the Supreme Court rejected this "alarming doctrine." ${ }^{8}$ Congress could confer such powers as it saw fit directly on such administrative offices as it chose to create-powers to be exercised on the responsibility of each incumbent, with whatever degree of independence he found it

\footnotetext{
'Myers v. United States, 272 U.S. 52 (I926); Humphrey's Executor (Rathbun) v. United States, 295 U.S. 602 (1935); see E. Corwin, The President: Office and Powers ch. 3 (1940).

${ }^{6}$ L. White, The Federalists: A StUdy in Administrative History, r789-I8or, chs. 2-4 (I948).

${ }^{\circ}$ Act of Sept. 2, $x_{7} 89$, I Stat. 65. White surmises that Hamilton drafted the statute. Whrte, supra note 5 , at $\mathrm{II} 8 \mathrm{n}$.

${ }^{7}$ Congressional preference for this arrangement is reinforced today by a consideration not yet apparent in I789: lesser officials can be summoned before congressional committees and made to testify about their statutory responsibilities, as the President cannot. This was the point that Congressman Chet Holifield (D., Calif.) made in opposing (unsuccessfully) Reorganization Plan 2 of I970 which created a cabinet-level Domestic Council to be presided over by a confidential assistant to the President. I26 Cong. REc. H43II 8 (daily ed. May I3, I970), H.R. REP. No. 9I-I066, gIst Cong., 2d Sess. (I970); Hearings on Reorganization Plan No. 2 Before the Subcom. on Executive Reorganization of the Senate Comm, on Government Operations, 9Ist Cong., 2d Sess. (1970); Hearings on Reorganization Plan No. 2 Before the Stucomm. of the House Comm. on Government Operations, 9Ist Cong., 2d Sess. (1970).

${ }^{8}$ Kendall v. U.S. ex rel. Stokes, I2 Pet. 524 (I838); see E. Corwin, Tre Constitution of the United States: ANalysis and Interpretation 478-80 (I953); L. White, The Jacksonians (I954).
} 
possible to maintain. Unity and hierarchy in the executive branch have seldom ranked high in the congressional scheme of order.

Down at least through the Igth Century it would have been generally agreed in principle that an office, or unit of government-apart from such a harmless hybrid anomaly as the Smithsonian Institution-which did not belong to the legislative or judicial branch must of necessity be a part of the executive; these three exhausted the logical possibilities. On that premise inferences of constitutional powers were often drawn from the attachment of one or another of these labels, as utility lawyers did in arguing against the finality of administrative decisions, by calling them "judicial," and as Chief Justice Taft did on behalf of the President's removal power in the Myers case, by calling it inherently "executive." But the establishment of the regulatory commissions, constituting a "headless 'fourth branch," as the Brownlow Committee characterized them, ${ }^{9}$ was not to be undone by name-calling. And when the Reorganization Act of I949 called the General Accounting Office and the Comptroller General-the lineal descendant of the Comptroller of the Treasury and inheritor of his statutory powers-"a part of the legislative branch of the Government,"10 the change was purely semantic. The Budget and Accounting Act of Ig2r had described the GAO only as "independent of the executive departments"11 - a description equally applicable to, for example, the Securities and Exchange Commission or the Veterans Administration-and the substantive change took place at that time, not by altering the statutory powers of the Office but by the reorganization that gave the Comptroller General a 15 -year term and made him virtually irremovable. Today, we may conclude, the labels have symbolic and propaganda uses, and little more. They do not make a "branch" of government cohesive. They are compatibles with hunting licenses for Presidents and congresses, each as they can, to augment their control over the organization of the executive branch.

The constitutionality of the Reorganization Plan method-of a presidential action that acquires the force of law after a stipulated lapse of time unless sooner vetoed in Congress-is another issue as to which a pound of practice weighs more than an ounce of doctrine. When the Congress in the Economy Act of 1932 included an authorization to President Hoover to promulgate reorganization by executive orders subject to veto in either legislative chamber, his Attorney General expressed the opinion that the proviso was unconstitutional. ${ }^{12}$ But he also recognized that it was inseparable, that without it there would have been no delegation. There the question has rested, "no tickee, no washee." Presidents have taken the power on the terms they could get.

\footnotetext{
9 Prestdent's Commitiee on Admintstrative Management, Report with Special Studies 32 (I937).

${ }^{20}$ Reorganization Act of $1949, \$ 7,63$ Stat. 203. Comptrollers General had repeatedly been calling themselves "agents of Congress" and the draftsman here went them one better.

${ }^{11} 3$ I U.S.C. $\$ 4 \mathrm{I}$ ( 1964$)$ (italics supplied).

1237 Op. AtT'y Gen. 56, 63 (I933). The subject is reviewed in E. Nobleman, Stapp Memorandum 89-r-6 (Feb. 9, 1965), prepared for the Senate Committee on Government Operations on the Constitutional and legal aspects of the Reorganization Act procedures.
} 
A collateral attack on a I933 reorganization order, by shipping concerns challenging the validity of regulations issued by the Department of Commerce, to which the old Shipping Board and its powers had been transferred, was lost in the courts. ${ }^{13}$ So far as I am aware no reorganization plan under the I939 or later statutes has been challenged in litigation. And issues that might arise if the veto power were claimed for a congressional committee or its chairman, instead of the full chamber (as has happened in connection with military construction authorizations and other subjects),${ }^{14}$ have so far remained moot.

\section{II}

\section{INITIATIVES AND OBJECTIVES}

The source of a reorganization initiative is closely related to the motives that inspire it and to the objectives in view, obviously. This section reviews experience with the major alternatives that have emerged. Its general argument is that while piecemeal reorganization proposals directly connected with material policy shifts may arise from any quarter, the initiative for government-wide reorganization studies and programs, once thought to be the province of Congress, has passed decisively to the Executive Office of the President. At least two sorts of reasons contributed to this result, one having to do with the difficulties of sustaining the degree of cohesion of interests in Congress necessary for securing legislation, and the other with congressional incapacity to translate the objectives proclaimed into self-executing standards. As reorganization became a politically attractive course, the Congress proved unable to institutionalize the process except by a delegation of authority that transferred discretion, and with it the initiative, and that recognized new and less congenial objectives.

The dissatisfactions that set major policy changes in motion commonly, if not always, include objections to the way previous policy has been administered. Often, indeed, expedient political tactics have dictated stress on complaints about administration rather than on the underlying grievances against policy. It is natural, therefore, that a reform package should contain some reorganization proposals. The initiative for these is then to be found somewhere in the coalition that proves successful in pushing the policy change through. In the case of the consolidation of agencies that became the Veterans Administration in 1930, for example, the impetus came largely from outside, from the clientele veterans' organizations. The overhaul of the Office of Education, on the other hand, in connection with the breakthrough in federal policy in that field in the mid-Ig6o's, was largely an inside job spurred by the top command in HEW. Jurisdictional rivalry furnishes another motivating impetus.

\footnotetext{
${ }^{13}$ Isbrandtsen-Moller Co. v. United States, 300 U.S. I39 (I937); Swayne \& Hoyt, Itd. v. United States, 300 U.S. 297 (r937); 37 Op. ATr'y. GeN. 238 (1933). The Economy Act of 1933 provided for a waiting period but no legislative veto. The lower court found the argument of implied congressional ratification conclusive. Isbrandtsen-Moller Co. v. United States, I4 F. Supp. 407 (I936).

14 See J. Harris, Congressional Control of Administration (ig64).
} 
Innovations in water resource policy authorized through the Interior or Public Works committees for the Reclamation Service or the Corps of Engineers, for example, will spark legislation from the Agriculture committees to give counterpart authority and programs to the Soil Conservation Service. The source of the initiative is more problematical when reorganization is approached in a government-wide context. Historically it was first asserted in Congress.

\section{A. Congressional Initiatives}

Instances of congressional investigations and committee reports on particular features of organization and especially on the financial operations of the executive branch can be found at least as early as $1795^{15}$ when Albert Gallatin took up the cudgels against the Secretary of the Treasury, Oliver Wolcott, over the issue of observing the limits of specific appropriations. House select committees and the House Committee on Public Expenditures from time to time, for example, in 1822,1828 , and I842, responded helplessly to resolutions seeking "reorganization" and "retrenchment in public expenditure." In an era when amateur members met for short sessions and worked without professional staff assistance, and when financial records were dispersed and uninformative, the committees were unable to cope with the mass of detail that a sustained study of the departments would have involved. After 1842 the committees on expenditures (by then, one for each department) virtually ceased to function.

A generation later the problem revived on a larger scale. The federal establishment expanded rapidly in the post-Civil War decades. Federal civilian employment more than tripled, from 5I,000 to 157,000 between $187 x$ and 1891 , although Treasury receipts rose only from $\$ 383$ million to $\$ 393$ million while expenditures went from $\$ 292$ million to $\$ 366$ million in the same period. ${ }^{16}$ Massive arrearages nevertheless accumulated in the major government offices: the Land Office and the Pension Bureau in the Interior Department, the claims and auditors' offices of the War and Treasury Departments. Hundreds of thousands of letters were unanswered, claims and applications remained undisposed, vouchers went unexamined, and so on. Apparently, complaints and frustrations arising from these delays and their attendant abuses, rather than the financial condition of the Treasury (which was in surplus for every year from I866 to I894), supplied the impetus for the first comprehensive congressional investigation of organization and procedures in the executive branch. It was set in motion by Senator Marion Cockrell (Dem., Mo.) who in I887 secured

15 A list of these is included in President's Comanssion on Econonx and Epficiency, The Nezd For a National Budget, H.R. Doc. 85I, 62d Cong., 2d Sess. (Igr2); the list was reprinted in G. Weber, Organtzed EFForts for the IMprovement of Methods of Administration in thiE United States (19I9), a publication of the Institute for Government Research. For an entertaining as wcll as instructive historical account of the futility of congressional efforts to control executive application of appropriations see L. Wilmerding, Jr., The Spending Power (I943).

${ }^{10}$ Buread of the Census, Historical Statistics of the United States, Colonial Times to i957, at 7 YO-II (Ig60). 
the appointment of a select committee of three Democrats and two Republicans, at a time when Republicans controlled the Senate, midway in Cleveland's first administration.

\section{x. The Cockrell Committee and the Dockery-Cockrell Commission}

With the aid of a clerk, subpoena power, and questionnaires to department heads, followed up by time-and-motion studies of its own, the Cockrell Committee in two years compiled enough detailed descriptive material on bureaucratic procedures to fill a report and appendices that ran to over 2,000 printed pages. It found plenty of grist for its mill, in a pre-typewriter era when clerks at $\$ \mathrm{r}, 000$ or $\$ \mathrm{I}, 200$ a year copied letters and accounts longhand into registers and journals, and when it was neither unlawful nor uncommon for appointed clerks to hire proxies, by private arrangement at lower rates, to come in and perform their daily stints. ${ }^{17}$

The results of the committee's labors were soon lost to sight. It did not touch any large organizational questions but confined itself to office methods in Washington. Field offices, where then as now nine-tenths of federal employees were located, were beyond its purview. Its principal statutory relic was the establishment of a Joint Committee on the Disposition of Useless Papers in the Executive Departments (itself later the butt of ridicule) and a law authorizing department heads, after submitting lists and getting the joint committee's approval, to dispose of old records as waste paper. ${ }^{18}$ Its main substantive accomplishment was to prod the Secretary of the Treasury, and less effectively the Secretary of War, to set up departmental committees to review and simplify procedures and record-keeping in their bureaus. In consequence, its chronicler concludes,

Workloads were increased, the workday was lengthened, proxy employment was prohibited, employees were shifted and many incompetents were dismissed. . . . Removal of the Chief of the Record and Pension Division of the Surgeon General's Office was forced by the Committee, because he had reported that no improvements were possible in his bureau. ${ }^{10}$

Six years later, at the opening of the second Cleveland Administration in 1893 , a more ambitious effort of the same general character was mounted, this time by a joint committee of six members, the so-called Dockery-Cockrell Commission. For the first time it employed outside experts as staff-three accountants, two of them, Charles W. Haskins and Elijah W. Sells, later the founders of a famous firm. Over the next two years the Commission filed some 29 reports, dealing mostly, as might be expected, with financial procedures and office methods, in the Land Office, the Treasury, and the Post Office. The Pension Bureau, the Office of Indian Affairs, and field offices generally-notorious patronage preserves-were excluded from its jurisdiction. It held no public hearings but accepted statements and made its own

\footnotetext{
${ }^{17}$ For an account of the Committee's work, and of the later Dockery-Cockrell Commission, see 0 . Kraines, Congress and the Challenge of Big Government (I958).

${ }^{18}$ Act of Feb. I6, I889, ch. I71, 25 Stat. 672 (I889).

$10 \mathrm{KRAINES}$, stipra note I7, at 45 .
} 
surveys. It compiled the first exhaustive list of laws relating to the organization of all departments and agencies. It offered numerous legislative and administrative recommendations, with varying degrees of success, and succeeded only later in introducing the typewriter. It got nowhere with a proposal to abolish the office of Solicitor of the Treasury as obsolete after the establishment of the Department of Justice in $1870^{20}$

The Commission's major accomplishment by far was the passage of the Dockery Act, ${ }^{21}$ which effected a general overhauling of procedures and consolidation of offices in the accounting operations of the Treasury and the Post Office. A half dozen lesser legislative changes were adopted, while others fell by the wayside. In the end the Commission put a price tag on the reforms it secured: a continuing annual saving in expenditures of $\$ 607,59 \mathrm{I}$, and another, of $\$ 449,928$ annually, on the recommendations that failed of adoption, in addition to its claims of intangible benefits. In the fiscal year 1895 , federal expenditures amounted to $\$ 356$ million.

Several incidental features of these episodes deserve notice. First, those who seek change run up against the jurisdictional sensitivities of those who are content with the status quo. The Commission, being authorized by its enabling resolution to report bills, encountered the jealousy of a standing committee as soon as it tried to do so. Its very first bill, altering the routing of postal certificates of deposit, though endorsed by the Postmaster General and the Secretary of the Treasury, was denounced in the Senate by members from both parties on the Committee on Post Offices, who argued that the Commission itself was unconstitutional and, besides, that its bill should be referred to their committee. To keep the peace, it entailed a month's delay in passage. Similarly, executive officials whose jurisdictions were endangered-the Postmaster General, the Commissioner of the General Land Office, the First Comptroller and the Sixth Auditor-came out in opposition; and a union of clerical employees was formed to lobby against the Commission's work.

Second, the reform of one generation, embodied in a statute, may become the reorganizer's target in the next. The Committee on the Disposition of Useless Papers, which mainly functioned to provide its chairman with a little patronage, was abolished by the Legislative Reorganization Act of $1946 .{ }^{22}$ The Dockery Act's consolidation of postal accounting in the Sixth Auditor's office, though the Postmaster General objected, did little harm in r894, considering conditions in the Post Office then and the nominal nature of the Sixth Auditor's connection with the Treasury. In operation his office was a part of the postal establishment, as it had been for sixty years. But when the Budget and Accounting Act of I92I lumped together the offices of the Comptroller of the Treasury and the six Auditors to form the new and aggressively independent General Accounting Office, the effect, barely noticed at the last minute, was to deprive the Post Office, alone among all the depart-

\footnotetext{
${ }^{20}$ Cf. H. Cummangs \& C. MaFardand, Federal Justice, chs. 8, ir (I937).

${ }^{21}$ Act of July 31,1894 , ch. I74, 28 Stat. 162.

${ }^{22}$ Act of Aug. 2, I946, ch. 753, 60 Stat. 8x2.
} 
ments, not only of the fundamental elements of an administrative accounting system of its own but also of legal authority to remedy its internal needs. When Postmaster General Farley in 1933 imported an energetic and capable business executive to be Comptroller of the Post Office and to modernize postal accounting, he found most of his tools in the possession of an uncooperative Comptroller General who was as little disposed to yield them as the Postmaster General had been forty years earlier. ${ }^{23}$

Third, reorganization studies helped launch a profession. When the Second Hoover Commission in 1953 farmed out its study topics to task forces, one of its contractors was Haskins and Sells, by then a management consultant as well as an accounting firm.

Finally, a more general lesson was learned regarding the underlying rationale of these two congressional initiatives. Functionally, they were an exercise in shifting the monkey of political responsibility from congressional to bureaucratic backs. The unforgivable official was the one who said no improvements were possible. The federal departments were indeed performing unsatisfactorily. Frustrated constituents, it is fair to suppose, took their complaints to their congressmen. When these complaints in turn were referred to the department heads and bureau chiefs the nearly uniform reply was a form of confession and avoidance. Yes, they said, there are delays because we are understaffed, for want of adequate appropriations to cope with the growing volume of business; the fault lies with the Congress; give us more money and we will improve the service. Senator Cockrell and his colleagues struck a popular note in rejecting this line. Let the departments, he said in effect, stop doing the time-honored but useless things they are now engaged in, and let them also install modern methods in place of their antiquated ways of doing what still needs doing; then they will find they can make out very well with their present allowances; the fault lies with them, and if they will not mend their ways we will show them how to.

Thus were the twin, interlocked goals of economy and efficiency invoked. They have ever since remained potent symbols. But they rest on the assumption that all right-minded observers can see, and agree upon, what are the useless and dispensable activities-in this case, almost exclusively, routine clerical functions in headquarters offices. The ratio of $\$ 600,000$ in savings to $\$ 356$ million in expenditures might have served as a caution against great expectations from reorganizations undertaken for these goals.

\section{Joint Committee on Reorganization, I921-23}

Only once has the congressional leadership been sufficiently moved to launch a broad congressional initiative toward reorganization. The occasion was the aftermath of World War I and Republican recapture of the government. The business

\footnotetext{
${ }^{23}$ H. Manshield, The Compptroller Generai I7I-75 (I939).
} 
community, and conservatives generally, were appalled at the size of the national debt and the scale of federal activities; the rg20 platform promised improved organization and methods. The agenda consisted mainly of the unfinished business worked up by the Taft Commission of rgI2 (of which, more presently) and its successors, public and private. The Retirement Act of r920, the Budget and Accounting Act of r92r, and the Classification Act of I923, all milestones in the renovation of the executive branch, were carried through to the statute books. The topic with which the Taft Commission had made least headway, however, and to which the Wilson Administration had meanwhile added complexities, was the rationalization of departmental jurisdictions. To this the congressional reorganizers addressed themselves.

In the lame-duck session after the rg2o elections a joint resolution on the Dockery Commission model was adopted on December I7; President Wilson let it become law unsigned. It created a Joint Committee on Reorganization, composed of three senators and three representatives. Reed Smoot ( $R$., Utah), soon to become chairman of the Senate Finance Committee, was its chairman. It was directed

to make a survey of the administrative services for the purpose of securing all pertinent facts ... also to determine what redistribution of activities should be made ... with a view to the proper correlation of the same . . . so that each executive department shall embrace only services having close relation with each other and ministering directly to the primary purpose for which the same are maintained. ${ }^{24}$

The committee was authorized to report bills to this end. Shortly after his inauguration in March I92I, Harding suggested that he be authorized to name a personal representative to cooperate with the joint committee and to be paid from its funds. This was agreed to. Harding named Walter F. Brown, a Toledo lawyer later to be Hoover's Postmaster General, who now became chairman of the reconstituted body. The President, after a cabinet session on the subject, blessed the undertaking in a letter to the committee:

The executive and cabinet are of one mind that a bill reallocating the government services upon the principle above outlined [related services grouped according to major purpose] should be prepared and strongly recommended to Congress for as speedy passage as possible. . . To this end we pledge your committee our hearty consideration. ${ }^{25}$

Chairman Brown replied that the "members of the committee are entirely in accord with your suggestion." If Congress were capable of such a thing, it seemed no enterprise was launched under fairer skies. W. F. Willoughby's Institute for Government Research was ready to help with a detailed blueprint based upon "the principles that should be followed by the National Government, or, for that matter,

\footnotetext{
${ }^{24}$ Act of Dec. I7, 1920, ch. 7, 4I Stat. 1083.

${ }^{28}$ Quoted in L. Short, Development of Nationad Administrative Organization in the United STATES $46 \mathrm{r}-62$ (I923).
} 
by any government, in providing for the organization of the administrative branch ....."26 The National Budget Committee, a civic group based in New York City, offered a less drastic proposal along similar lines. The Budget Bureau, though empowered by its recent statute to cover the same ground, prudently kept out of the way. The Joint Committee shrewdly avoided one major source of potential controversy: it was not authorized to propose either the contraction or the enlargement of any existing government service, but only its organizational location. It also escaped partisan controversy.

The whole effort nevertheless came to naught. In January, Ig22, the committee presented a plan informally to the President; it was discussed with his cabinet members collectively and individually. A year later the President returned a modified and less ambitious plan to the committee, whose life was extended in March, I923, to July I, I924. Before that date arrived the President was dead, and his administration clouded in scandal. The plan was moribund and President Coolidge did nothing sufficient to revive it. The committee, though it held hearings in January, I924, expired with its report, which Coolidge transmitted to Congress. ${ }^{27}$ It recommended an elaborate plan, at once comprehensive and specific. Bills were introduced and debated the next year but nothing was enacted.

This experience has been taken, probably correctly, to show that Congress is incapable of effecting, primarily on its own initiative, a comprehensive reorganization of the executive branch by direct statutory reassignment of jurisdictions across the board. If so, it would follow that if such a thing is to be done by Congress it must be done piecemeal; and conversely, that if it is to be done comprehensively it must be by way of a delegation that puts on the President a large measure of responsibility for initiating action, for its timing, and for its particular form.

It may be questioned whether one episode warrants so broad a conclusion. Some factors in the Joint Committee's failure-notably the collapse of public confidence in the integrity of several cabinet officers and the death of President Harding-were certainly specific to the time and circumstances. It is also pertinent that several main features of the Harding cabinet's proposal-consolidation of the army and navy in a department of defense, the transfer of non-fiscal agencies out of the Treasury, and the creation of a department of education and welfare-have subsequently been adopted by piecemeal action. The fact remains that only once since rg23 has a congressional committee mounted a comparably comprehensive study of executive branch organization, and this exception-the Byrd Committee in 1937-tends to prove the rule. Moreover, the Joint Committee encountered some generic difficulties that go far to explain the outcome.

\footnotetext{
${ }^{36}$ INSTITUTE for GovernMent Research, Reorganization of the ADMinistrative Branch of the NaTIONAI GOVERNAIENT at vii (I923); SHORT, supra note 25, at 462-70. Note the confident generalization of applicable principles.

${ }^{27}$ Message of June 3, 1924, S. Doc. No. I28, 68th Cong., Ist Sess. (1924). The recommendations included the transfer of the General Accounting Office bodily to the Treasury.
} 
First, though Harding's cabinet could agree in principle at the outset on the generalities he stated, these yielded no single and unambiguous result in application; choices remained open to argument. Second, most department heads, if not all, were, in matters of jurisdiction, servants of the bureaucracies they headed-readier to take than to give up. The difficulty of reconciling views within the executive branch entailed a delay and loss of momentum over two years. The Joint Committee was in no position to knock heads together. Other factors influenced the Congress more directly. Clearing unrelated bureaus out of Treasury and Interior, unless it left them orphans, meant setting up a new department or departments for education, welfare, and health. The organized professions in these fields, then and for the next quarter century, opposed the elevation of these functions to cabinet status as a threat of increased federal control. Consolidating public works in one agency meant dislodging the Army Engineers from their historic connection with rivers and harbors. Finally, a sort of negative log-rolling-I will oppose what you don't want if you will oppose what I don't want-set in. It seems fair to conclude that the first lesson of the Joint Committee's experience was the abandonment of the Dockery Commission's first premise.

Nothing in this episode, however, disturbed the long-standing tradition that the Congress, when sufficiently moved, could and would reorganize a particular function. The transformation of a segment of the Corps of Engineers into the Inland Waterways Corporation, and the major changes in the handling of prohibition enforcement during the same period were proof enough of this.

\section{The Byrd Committee, $1936-1938$ and Later}

What the congressional leadership never tried again was attempted in a very different context by a dissident Democrat in the Senate, Harry F. Byrd of Virginia. In February, 1936, he secured the adoption of a resolution setting up a select committee, of which he became chairman, "to investigate the executive agencies of the Government." 28 This move probably influenced the manner and timing of President Roosevelt's announcement, if not his actual decision (which had been under discussion for some months), to proceed with the appointment of his own Committee on Administrative Management.

Byrd had earlier made something of a reputation as Governor for reorganizing Virginia's state government and had employed the services of Luther Gulick and the Institute of Public Administration in New York City in doing so. By 1936 he was in right-wing opposition to the President and to the New Deal in virtually all its aspects-a true believer in retrenchment. With staff help from the Brookings Institution his committee conducted a series of voluminous and detailed studies of federal agencies. Despite advance efforts on both sides to prevent conflict by an agreed division of labor, the Byrd Committee reports stood in sharp contrast, in method,

\footnotetext{
${ }^{28}$ S. REs. No. 2I7, 74th Cong., 2d Sess. (I936).
} 
plan, and conclusions, to the work of the President's Committee on Administrative Management proceeding simultaneously; the reports furnished ammunition that Byrd used in helping to defeat Roosevelt's reorganization bill in $1938{ }^{29}$

Whatever his capacity as a spoiler, however, Byrd's committee proved quite unable-and this is the important point here-to make headway with its own proposals. Four bills that the Senator introduced in 1937 failed to reach the floor after hearings by his committee. Fundamentally, this outcome may be thought to illustrate the inherent handicap of an anti-administration member of the dominant party, although the Republican-Southern Democratic coalition, formed the next year, was successful on some other issues. Byrd's difficulties here were compounded by the fact that another of his targets was Jesse Jones' Reconstruction Finance Corporation, with its immense resources and broad authority to lend and spend. Later on, after World War II and after Jones' political demise, Byrd was in on the killing of the RFC. But at this juncture the solid congressional support that Jones enjoyed embraced many of the conservative senators who were otherwise Byrd's natural allies. They would not follow him down that path to "economy." A reorganization initiative in Congress that aims at effects across the board needs more than a factional base.

One later congressional initiative needs notice, the work of the Jackson Subcommittee on National Security Policy during the latter part of the Eisenhower Administration, when the Democrats were in control on the Hill and Lyndon Johnson was the Senate Majority Leader. Using the broad charter of the parent Committee on Government Operations, and so bypassing the jurisdictions of the Armed Services and Foreign Relations committees, Senator Henry M. Jackson (Dem., Wash.) secured staff studies and expert testimony that challenged a good deal of contemporary doctrine on cold war topics, and therewith the fairly elaborate organizational machinery and procedures the Administration had built up to develop policy and supervise its carrying out. The Subcommittee succeeded in pointing up issues that became prominent in the Ig60 presidential campaign. But when the election restored the executive branch to Democratic control, and President Kennedy installed an energetic reorganizer, Robert McNamara, as Secretary of Defense, the Jackson Subcommittee became a fifth wheel.

Two generalizations emerge here. First, there is more room for congressional initiatives in reorganization when the White House is in the hands of the other party. And second, the broader the scope of the executive jurisdictions encompassed in a reorganization survey, the less susceptible it becomes to specific congressional solution, since additional committee jurisdictions also become involved. Even in Congress the sentiment is widespread, if not unanimous, that a general reorganization of the executive is like a general tariff revision; for Congress it is a tempting prospect that cannot be brought off.

\footnotetext{
${ }^{20}$ S. Rep. No. I275, 75th Cong., Ist Sess. (I937). See R. Polenberg, Reorganizing Roosevelt's GOVERMIENT, I936-I939, at 3I-4I (I966).
} 


\section{B. Outright Statutory Delegation}

At the opposite end of the spectrum from congressional initiatives is a statutory delegation to an executive official to effectuate changes in organization by his own fiat. At lower levels in the executive hierarchy this is a common method, the more so because an implied delegation may be ratified by recognition in subsequent appropriations. Statutes and committee attitudes vary widely in the latitude they allow on this, from agency to agency and subject to subject. The reorganization in the executive office instituted by Plan 2 of 1970 , renaming the Budget Bureau and setting up a Domestic Council, for example, could have been accomplished in substance by the President acting alone. The plan method was utilized instead for its greater psychological impact. But this opened up complicated questions of redelegation and of confidentiality and privilege, not pertinent here, that caused the House Government Operations Committee to recommend a veto of Plan 2, unsuccessfully as it turned out. $^{30}$

An untrammeled delegation of reorganizing authority, by definition, vests the initiative, in law, entirely with the executive. But such a grant on a scale comprehending the executive branch has come to the President on only three emergency occasions, and then only for limited periods: in the Overman Act of 1918, in the Economy Acts of March 3 and March 20, I933, and in the War Powers Act of December I94x, all of which carried expiration dates. ${ }^{31}$ The pertinent point here about these instances is not only their temporary character, but also the fact that their rationale and objectives were altogether different from the congressional initiatives previously considered. These grants were made to enable the President to cope with needs, and in ways, not immediately foreseeable, and quickly, so as to absolve the Congress of responsibility for hindering remedial measures. These objectives were far from the goals of economy and efficiency that congressional reorganizers talked about, and the delegations tended away from the institutionalization of the process. Being addressed to temporary conditions they have left little lasting impression but the precedent ${ }^{32}$ and the general lesson that although in a sufficient emergency more

\footnotetext{
${ }^{80}$ The Executive Office in 1970 was a large conglomerate of units formed, some by statute, some by reorganization plan, some by published executive order and some altogether informally. Congressman Holifield argued, in connection with the executive privilege point already noted above at note 7, stipra, that if the Budget Bureau's statutory functions were all transferred to the President, for retention or redelegation at will, they could be redeployed without congressional review and placed in hands unresponsive to congressionial inquiry. In the terms of this article, such a development would tend to de-institutionalize executive-congressional relationships. See H.R. REP. 9r-1066, supra note 7, at 6-13.

${ }^{81}$ Act of May 20, I9I7, ch. 77, 40 Stat. 556; Act of Mar. 3, 1933, ch. 212, $\$ 401,47$ Stat. 1517; Act of Dec. 18, x941, ch. 593, 55 Stat. 838. The Emergency Relief Appropriation Act of 1935 and the Defense Production Act of I950 both authorized the President in swceping terms to utilize cxisting agencies or to create new ones, and to delegate and redelegate his powers to them as he saw fit, in order to effectuate the statutory purposes. But these purposes, though broad, by no means encompassed the entire executive branch.

${ }^{82}$ Exec. Order No. 6166 of June Io, I933, is an exception to this generalization: formulated by the Budget Bureau, it centralized civilian disbursing and strengthened centralized procurement in the Treasury and instituted the first Budget control over the flow of appropriated funds to departments, through quarterly apportionments.
} 
people, even more members of Congress, look to the President for salvation than elsewhere, an emergency concentration of power in his hands will not outlast either his political downfall or the passing of the sense of urgency.

\section{Public Commissions}

A public commission, as a means of conducting studies and proposing a program of action, has at least two inherent attractions. It can be expected to transcend parochial interests and, by taking high ground, erect a standard that will be visible and command public support for its proposals. It confers legitimacy on the enterprise. And, with some attention to its composition, it can also hope to mediate, or at any rate to anticipate and mitigate partisan, interest group, and executive-legislative clashes in the formulation of its recommendations. So the device has come into frequent use in a variety of policy areas, both by public authorities and by private foundations. ${ }^{33}$ For the purpose of furthering goals of general federal reorganization, as distinct from program revisions in specific policy fields, four official commissions have functioned in this century, each quite different from the others. Three are associated with the names of conservative Republican Presidents. Only two saw material changes brought about directly as a result of their labors. All but the last learned something from their predecessors. The obstacles they encountered tell something of the generic limitations of the method.

\section{The Taft Commission, 19ro-rgr3}

President Taft created the first, the President's Commission on Economy and Efficiency, in the wake of the rgro elections which ended a long period of Republican control of the House and, with the retirement of Nelson Aldrich, foreshadowed the break-up of the dominant Republican oligarchy he had headed in the Senate. Taft had started more informally a year earlier with a request to Congress that secured a rider on the sundry civil appropriation act for IgII:

To enable the President, by the employment of accountants and experts from official and private life, to more effectively inquire into the methods of transacting the public business of the government in the several executive departments ... with the view of inaugurating new or changing old methods ... sa as to attain greater efficiency and economy therein, and to ascertain and recommend to Congress what changes in law may be necessary to carry into effect such results of his inquiry as cannot be carried into effect by executive action alone ... [there will be allocated] one hundred thousand dollars. ${ }^{34}$

The arrangements being thus left to him, Taft turned to his secretary, Charles D. Norton, who engaged Frederick A. Cleveland, then head of the New York Bureau of Municipal Research, to take charge of the inquiry; it got under way September, IgIo.

\footnotetext{
${ }^{\text {sa }}$ See F. Popper, The President's Conmisstons (1970) for a discussion of some recent examples.

${ }^{84}$ Act of June 25 , I9Io, ch. 384,36 Stat. 703 . Successive supplements brought the total over a threeyear period to $\$ 260,000$.
} 
But in the light of the election returns, as the partisan base for cooperation crumbled, the undertaking was reconstituted as a commission of six in the spring of rgrr. ${ }^{35}$ It comprised three experienced officials, including W. F. Willoughby from the Census, and three private citizens, including Cleveland, who became chairman, and Frank J. Goodnow, then professor of administrative law and municipal science at Columbia and author of well known treatises.

The Commission's contributions turned out to be almost purely educational, and promotional in a long-run sense. It addressed its studies to five major subjects: (I) a national budget system, (2) departmental and bureau organization and jurisdictions, (3) personnel practices, (4) financial procedures, and (5) business practices and methods. The last two of these were by this time familiar topics. A great deal of detailed information about them was collected and some changes were instituted as a result of administrative action, particularly through circulars from the Comptroller of the Treasury-Walter W. Warwick, a member of the Commission-looking toward standardization of departmental accounts. These accomplished the only actual changes in practice made as a result of the Commission's efforts. A published report on personnel problems-methods of appointment, efficiency ratings, mandatory retirement for age-dealt with matters that were the subject of legislation a decade later.

As to organization, the Commission compiled an exceedingly detailed inventory, running to over 1500 pages and purporting to catalog, though in a very formal and unrevealing way, the geographical and hierarchical location and duties of every extant unit of every federal department. From this overwhelming and unanalyzed factual mass, however, only a few specific recommendations emerged, mostly having to do with rationalizing and locating elsewhere some of the non-fiscal activities under Treasury jurisdiction-conclusions that scarcely needed the factual compilation. No action resulted from this first serious foray into a complex and sensitive subject, beyond grist for the mill of future talk about "overlapping and duplication."

From the beginning, however, the Commission gave its highest priority to the project for which it is chiefly remembered, the need for a national budget; and in pursuing that topic brought on a brief and symbolically characteristic showdown in presidential-congressional relations. Its report entitled The Need for a National Budget later furnished material for the campaign that eventuated in the passage of the Budget and Accounting Act of rg2I. But the Commission, not content with a document, undertook to make a laboratory demonstration, at least, of "how to do it." In this endeavor it had Taft's earnest and active support. For its report it had worked out, using the current year's figures, a classification of expenditures, by appropriation headings, organization units, character (i.e., capital, operating), function and object (i.e., salaries, travel, etc.) Taft in June, rgr2, directed his department heads to get

\footnotetext{
${ }^{35}$ For the facts in this section I have relied largely on WeBER, supra note 15 . Weber had aceess to W. F. Willoughby's records and worked under his direction in the Institute for Government Research (later merged into the Brookings Institution), but his account eschews interpretations.
} 
up their forthcoming estimates for fiscal I9I4 both in the usual line-item form for the Secretary of the Treasury's annual Book of Estimates, and also in accord with the Commission's classifications.

This directive aroused the ire of the House Appropriations Committee chairman, now a Democrat, who told the House that "Congress knew best the character and extent of the information it desired ... [and] that it would not be wise for Congress to abdicate, even by implication, its prerogative in this matter." He thereupon added a rider to a pending appropriation bill:

Section 9. That until otherwise provided by law, the regular annual estimates ... shall be prepared and submitted . . . only in the form and at the time now required by law, and in no other form and at no other time. ${ }^{36}$

Something of substance was ultimately at stake here, of course, in the difference between line-item and lump-sum or functional budgeting, although, with the information provided in both forms, the Committee was deprived of nothing tangible at the moment. But the prospect of a change in bargaining relationships, if the new form. displaced the old, was enough to trigger the alarm.

The Committee's slap provoked the President in turn, who reiterated his instructions to department heads in September, I9I2, invoking his constitutional right to recommend measures to Congress, and thereby to the people:

If the President is to assume any responsibility . . . it is evident that he cannot be limited by Congress to such information as that branch may think sufficient for his purpose. ... It is quite within his duty and power to submit to Congress and the country a statement of ... estimates in the form he deems advisable. And this power I propose to exercise. ${ }^{37}$

Accordingly, in the last week of his term, February 26, I9I3, the President transmitted to the expiring lame-duck session of the Sixty-second Congress the Commission's model demonstration, together with a number of supplementary statements. The election returns of the previous November, meanwhile, made that gesture that Commission's last official act.

The Commission raised the sights in its view of what reorganization was for, and earned a respected place in the intellectual history of professional public administration. It marked the first congressional acknowledgment that the President had a legitimate concern for reorganization, however fragile that acknowledgment was. It also gave an impetus to the reform movement that survived the indifference or preoccupation of the Wilson Administration. Willoughby, leaving government service, became head of the Institute for Government Research, founded with philanthropic support in $19 \mathrm{I} 6$, and in that capacity championed reorganization causes for the next dozen years. Herbert D. Brown, the Commission's personnel expert, found official and congressional sponsorship, first in a niche in the Civil Service Commission,

\footnotetext{
${ }^{80}{ }_{5}^{8}$ CONG. REC. 13, I42 (I9r2).

${ }^{37}$ WEBER, supra note 15 , at 90.
} 
and, from Igr6 on, as head of an independent agency, the Bureau of Efficiency, which lasted until 1933. The Taft Commission, nevertheless, as the President's creature, proved unequal to the task of mediating with a Democratic Congress. In fairness, probably no such commission could have surmounted the political tumult that overwhelmed the Taft administration in 1912. Institutionalization requires a greater stability in expectations.

\section{The Brownlow Committee, 1936-1939}

The President's Committee on Administrative Management, set up in I936, is included here in the category of commissions because it made a public report, to the Congress as well as to the President. In other respects it resembled the presidential task forces considered below. More than the Taft Commission, it was a presidential enterprise, created by a letter to its chairman and announced in parallel letters from the President to the Speaker and Vice President. It had only the minimum congressional sanction of a line in a deficiency appropriation act, without a congressional mandate other than submission of its report. ${ }^{38}$ Roosevelt appointed its three members. There would have been more if ex-Governor Lowden's health had permitted him to accept an offered place; a Republican, a pioneer state government reorganizer, and a onetime presidential aspirant, he would have given the outfit an overtly bipartisan cast. When he declined, other names were canvassed but Roosevelt decided to settle for a snug group, knowledgeable and congenial, with a minimum of uncertainties. He had talked with two of them a number of times earlier, in the preliminary planning, but when the work got under way he cut off further communication with the committee until after the November elections. When he saw the draft report he found little to alter and much to his liking.

The congressional leaders, on the other hand, although cordially invited at the beginning to set up select committees to cover the same ground, got no advance inkling of the contents of the Brownlow report until the very eve of its publication and transmittal. Nor, with one or two exceptions, did anyone in the executive branch outside the White House. Neither did Senator Byrd, who found in that fact evidence of bad faith and another ground for his opposition to the recommendations after he learned what these were. In the House the leadership was friendly in the beginning, by reason of personal ties between Brownlow and the speaker, but the Appropriations Committee chairman balked. In the Senate the leadership was indifferent until the report appeared.

The substance of the Brownlow report does not need recapitulation here. ${ }^{30}$ For

\footnotetext{
${ }^{38}$ Act of June 22, 1936, ch. 689, 49 Stat. 1600. The Committee was released from the mandate stated there, to look for duplications that could be abolished, by an understanding with Chairman James P. Buchanan (D., Texas) of the House Appropriations Committee that involved turning over \$ro,000 of its appropriation to Brookings in support of the latter's studies for the Byrd Committee. L. BrownLow, A PASSION FOR ANONYMTTY 355 (1958).

${ }^{80}$ President's Committee on Administrative Management, Report with Specinl, Studies
} 
the first time, in an official study of this scope, it was short; it viewed the subject from the President's perspective; and it argued a simple theme, "the President needs help." The project was favored by three circumstances: the Committee was unanimous in presenting coherent views and proposals that coincided with ardent views of the President's; the President, at the time the report was made, had just won an overwhelming electoral victory and had majorities of over two-thirds of his party in both houses of Congress; and the Committee, by taking existing levels of substantive government activities as given and avoiding talk of transfers of jurisdictions among departments, minimized opposition by bureaucratic clienteles. ${ }^{40}$ From the President's standpoint the report was an unqualified success.

These advantages were not enough to translate it into legislation, however, and in retrospect it seems plain that nothing the Committee could have done differently would have saved it. The defeat of the President's plan is attributable, rather, in the broad sense, to the convergence on Congress, at an unpropitious time, of highly emotional sentiments aroused by an incongruous combination of influences; and more narrowly, to the loss of two critical parliamentary moves, the first in the Senate and the second in the House. The general explanation is part of the larger history of Roosevelt's setbacks in the first half of his second term. The vote on the reorganizaton bill came in the ebb of the 1938 recession, in a mood of widespread frustration when Democrats were badly divided on many issues. But this by itself explains too much, for such major New Deal measures as the Fair Labor Standards Act and the revised AAA were enacted in that same session. The processes of coalition-building that passed these two and defeated the other were distinct.

Roosevelt, fresh and confident, sent the Brownlow Committee report to Congress with his endorsement on January I2, I937. Early in February, and again without advance congressional consultation, he sent up another message, proposing to reorganize the Supreme Court. He read his reelection as an authorization to make over the basic relationships of his office with the rest of the government. Immediate success depended on securing these two legislative measures. The Court bill preempted the political stage, and the Senate's time, until the summer, when it was defeated.

By then the Byrd Committee was holding its hearings. But the political connection between the two reorganization bills, judicial and executive, did not emerge until the Senate took up the latter in the next session, at the end of February, I938.

(1937). See also Brownlow, supra note 38; H. Emmerich, Essays on Federal Reorganization, ch. 3 (1950); R. Polenberg, Reorganizing Roosevelt's Government (I966); B. Kari, Executive ReorgaNization AND Reform in the New Deal (Ig63).

${ }^{20}$ These actions minimized, but did not eliminate it. Friends of the Forest Service were alarmed that the well known covetousness of Secretary of the Interior Harold Ickes might be gratified; see PoLENBERG, supra note 39, chs. 3, 4. The report advocated taking the independent commissions apart, transferring important GAO functions to the Treasury, and remolding the Civil Service Commission. Friends of these agencies testified against the reorganization bill, as did the American Legion, the AFL, and many other organized interests. 
After six weeks of mounting pressures in opposition, an omnibus bill passed, substantially intact, by a close margin. At this juncture an unfriendly ruling by the Vice-President sent it, not to conference but to floor consideration in the House, which had passed two bills embodying parts of the program the previous August. There, after ten days of a continuing build-up of opposition-by conservatives who had helped kill the Court bill and now saw a chance for another stroke; by the economy bloc led by Senators Byrd, Bailey and Burke; by friends of the Forest Service; by civil service reformers opposed to a one-man personnel administrator; by some Catholics opposed to a Department of Welfare; by Father Coughlin and his radio listeners-a stampede to beat the "dictatorship" bill moved enough members to carry a recommittal motion, 204 to 196 , with 29 not voting. It was a near miss, but a miss nonetheless.

Defeated on both bills, Roosevelt turned in the summer and fall to a third course aimed at making good his conception of the presidency. Invoking party discipline, he campaigned to purge some leading Democrats who had opposed him. This failed too. The congressional elections returned reduced Democratic majorities, but these included, with one or two exceptions, the special objects of the President's attacks.

It was in this state of executive-congressional relations that the Reorganization Act of 1939 was put together and passed without serious controversy, except for one hurdle in the Senate, the following April. This time the President consulted the legislative leaders and they decided what could be salvaged. Congressman Lindsay Warren (D., N.C.) of the House Select Committee, perhaps drawing on the office of the legislative counsel, was responsible for the bill, and assured the House that he had not consulted the Brownlow Committee.

In short, the Brownlow Committee proved to be a device superior to its predecessors in the field as a means of formulating a program for the President, and it swung the main objective of a reorganization program away from "economy and efficiency" to the capacity of the President to wield the resources of the executive branch. But it was not an institution that, by repeated use, gave promise of containing or stabilizing the mercurial relationships between the President and Congress. The legislative veto which Congressman Warren introduced into the reorganization plan procedure of the I939 Act, did hold out the prospect of becoming such an institution.

\section{The First Hoover Commission, 1947-1949}

The Commission on Organization of the Executive Branch was the first, and so far the only successful, essay in overt bipartisan collaboration in the formulation of a comprehensive reorganization program. Late in 1945, with his War Powers Act authority running out, President Truman had secured the revival of a reorganization statute on the 1939 model. But the Reorganization Act of 1945, though it required a concurrent resolution for the legislative veto, proved too frail a vessel for heavy 
cargo in the postwar storms over domestic issues, particularly public housing and labor relations. The House voted to reject all three of the reorganization plans that Truman submitted in the spring of 1946 ; two were rescued by narrow margins in the Senate. After the fall elections of that year he confronted a Republican majority in the House and two of his three 1947 reorganization plans again encountered adverse votes there; the Senate saved one and doomed the other. The single plan sent up in 1948, a second try for the transfer of the employment service to the Labor Department, defeated in 1947, was defeated again. Executive-legislative conflicts and, what was not quite the same thing, partisan conflicts were running high for the duration of the 8oth Congress. Truman muted them in some ways and aggravated them in others.

The abortive mission of the I945 law was superseded, in these circumstances, while it still had nearly a year to go, by an altogether different approach that opened up more far-reaching possibilities of action. The Hoover Commission served as an intermediary third party in the field of governmental reorganization; it enjoyed a higher degree of confidence from both sides than they had in each other and could communicate freely with both when direct communications were difficult. To that end it was a mixed body, carefully balanced in several ways. Of its twelve members, six held public office, two each from the Senate, the House and the executive branch; and six came from private life although all had had extensive experience in and with government. Six were Republicans and six Democrats; and four each were appointed by the President, the President pro tem of the Senate and the Speaker, respectively.

As an advisory body, the Commission's influence depended on the prestige of its members, the intrinsic merit of its proposals, the public backing it could arouse, and the degree to which its work turned out to suit the purposes of the President and of dominant elements in Congress. Unlike the Brownlow Committee, which did an inside job for the President, it was an autonomous body, committed to neither branch or party. Its terms of reference were sufficiently ambiguous to admit a good deal of latitude in the choice of objectives and emphases. In that ambiguity lay its opportunities and its risks.

The establishment of the Commission was a Republican and congressional idea. As in I9r9, the federal debt and the current budget were alarmingly large, and an organizational shakedown, after the tumult of depression and war, had widespread appeal, at least in principle. But the change in party control in the House, for the first time since 1930, gave the congressional sponsors of the Lodge-Brown Act ${ }^{41}$ more definite notions of the help they could expect from the commission they created. Republicans, again as in I9I9, were confident of winning the forthcoming elections. Congress had preferred tax cuts to debt retirement in a period of inflation, and wanted budget cuts in the abstract but encountered opposition when specific pro-

\footnotetext{
¿x Act of July 7, I947, ch. 207, 6I Stat. 246.
} 
grams were threatened. Members like John Taber (R., N.Y.), chairman of the House Appropriations Committtee, saw in the Commission a means of exposing waste on a large scale and getting an authoritative blueprint for "painless economy" by dismantling some of the New Deal at the same time. Taber's axe swung on many targets, but he pledged and gave the Commission all the funds it asked for-ultimately, \$2 million.

President Truman, from a quite different set of calculations, welcomed the proposal and supported the enabling legislation. He too saw opportunities in it, and for him it foreclosed few options that were otherwise open. He is reputed to have had a hand in the selection of the Commission's chairman and maintained cordial relations with ex-President Hoover throughout the study. He directed the Budget Director and all departments and agencies to cooperate fully; some of these officials saw opportunities also for changes they had vainly wanted for a long time.

A collegial body of twelve, so diversely composed and viewing such an array of problems, might have turned into a hung jury, hopelessly divided; or it might have confined itself to consensus on platitudes. That the Commission did neither is largely attributable to the prestige and labors of its chairman. He acted as his own staff director, engaged the numerous task forces assigned to investigate particular topics, supervised their work closely, and put the unmistakable stamp of his terse literary style on the Commission's own reports. For the task force studies he turned instinctively to business leaders, management consultant firms, and the like, chiefly, rather than to academic resources; the outlook of business administration pervaded the enterprise. The Commission members themselves, however, with two or three exceptions, were men in public affairs, not business executives. Congenially to their views and his own, and in contrast to any previous effort in this field since the Taft Commission, the Hoover Commission "thought of its project not only as a job of mobilizing information but also as a job of mobilizing influential leaders behind the idea of reorganization. ... The Commission viewed its task from the outset largely as one of public relations ... a much heralded project of mass data-gathering aimed at bringing support to the recommendations...." ${ }^{2}$ The reports, nineteen in all, were issued one at a time for maximum news coverage. They were usually short, with little elaboration of reasons. They were meant, like press releases, to be read by laymen. A Citizens' Committee was formed, and private funds were raised, to publicize them and promote action on the reports. They assumed the air of conventional wisdom. By a halo effect they stimulated the formation of "little Hoover Commissions" in many states, addressed to state government reorganizations.

The specific results of this monumental endeavor were impressive if not startling. The Commission listed some 277 distinct recommendations it made. Later the Citizens' Committee was able to count over roo of these targets, little ones and big ones together, as battle trophies. Congress enacted, with modifications, several

\footnotetext{
\$2 Emmerich, supra note 39, at 98.
} 
major items on the agenda by ordinary legislation: the Military Unification Act, the State Department Reorganization Act, the establishment of the General Services Administration, the revised Classification Act, all in r949. In addition the Reorganization Act of 1949 was adopted, under which President Truman submitted 35 reorganization plans over the next two years; 27 of these were sustained. Further recommendations, notably the switch to a performance-type budget presentation in I950, were carried out by administrative action.

In the larger political sense of their functional effects on the American political system, the Commission's reports, which avoided like poison any mention of the Brownlow Committee, made the doctrines of that Committeee orthodox. They tended to strengthen President Truman's hand with Congress. And they effected no measurable savings in expenditures. In the light of the Commission's origins these results are paradoxical.

The latent ambiguity in the Commission's mission has already been noted. In a way, Hoover personified it. Having once been President, he had very definite notions, undimmed by the intervening years and events, about the need to strengthen the managerial capabilities of the office. As he put it in his letter transmitting to Congress the Commission's first report, General Management of the Executive Branch: "we must reorganize the executive branch to give it the simplicity of structure, the unity of purpose, and the clear line of executive authority that was originally intended under the Constitution." 33 If that was the mission, then the scope and scale of federal functions were not in issue.

But Hoover was equally convinced that the government was up to its neck in many enterprises it ought to get out of, the retrenchment of which would greatly reduce Treasury outlays, and so yield "savings," in his pre-Keynesian vocabulary. If the discovery and recommendation of such "savings"-beyond changes that would reduce overhead administrative costs-were the object, then the Commission had to pass judgment on the worth of a host of federal activities. A good deal of the time the Commission simply sustained the ambiguity by carrying water on both shoulders, as its enabling act had done. For example, the first report, after talk along the lines just quoted, concluded with a passage asserting in general terms that the savings from a thoroughgoing reorganization "can amount to billions."

A showdown occurred in the summer and autumn of r948, as the presidential campaign began to intensify. It is revealing both as an explanation of the paradoxical outcome and as demonstrating a major limit to the utility of an advisory commission of this general type in this field. It emerged partly in the form of dissenting statements from certain commissioners, appended to particular reports, but chiefly in the way the Commission ignored recommendations from some of its task forces. The task forces on the Department of Agriculture and on federal-state rela-

\footnotetext{
${ }^{4}$ Comaristion on Organization of the Executive Branch, Generat Management of the ExecUTIVE BRANCH, at viii (1948).
} 
tions, for instance, and the Brookings report on welfare-especially the old-ageand-survivors insurance program-and most of all the Haskins and Sells report on lending agencies and federal business enterprises, all took their mandates to include substantive appraisals of underlying policies, and urged drastic federal withdrawals. At that juncture, if the Commission had adopted any of these recommendations to anything like the extent proposed, this would have amounted to a virtual endorsement of the Republican platform and the candidacy of Thomas E. Dewey. Even trying to take positions on these matters, as the watered-down Commission report on Federal Business Enterprises showed, split the Commission wide open.

Truman's electoral victory and the restoration of a Democratic majority in the House reinforced the lesson. The condition of bipartisan cooperation in a broadscale reorganization effort was to take the existing scope and scale of government programs in controversial areas as given, and confine the mission to structural rearrangements. It is ironic that this fresh example of the utility, for some purposes, of maintaining a distinction between politics and administration should have come just at a time when academic students of public administration, breaking away from the older Goodnow tradition, were insisting on the inseparability of the two.

This is not to say that the Commission's recommendations were wholly neutral in impact, but only that in a situation of political contest over policy there was room only for reorganization proposals which did not raise that issue directly. The Commission's views plainly favored the President and department heads, within the executive branch; and as between Congress and the executive they favored the executive. This suggests a second lesson on the utility of a mixed commission. The inclusion of senators and congressmen in the Commission's membership may have been a price of securing the enabling act, to provide a balance of viewpoints on executive-legislative issues. At the least it was a device to contain conflicts and, by participation and immersion, to educate and animate the congressional members to work actively on behalf of the implementing legislation afterward.

Both expectations turned out to be illusions. The congressional members occupied midway positions on the scale of frequency of individual dissents recorded in the reports, and had little discernible influence on the recommendations. The Commission did not venture beyond its assigned province, so that its measures for strengthening institutions in the executive branch were not accompanied by any countervailing proposals for strengthening congressional oversight, such as the Brownlow Committee had offered.

As for the implementing legislation, the strategy of cooptation may have helped in the House, where the Commission's draft bill sailed through without serious difficulty. Not so in the Senate. ${ }^{44}$ In the 8Ist Congress, assembling in I949, Senator Aiken (R., Vt.) graduated out of the Committee on Expenditures, which had the bill in charge, and so was in no position to give it a boost. Senator McClellan (D.,

\footnotetext{
${ }^{4}$ See Heady, The Reorganization Act of 1949, 9 Pus. AD. Rev. I65 (1949).
} 
Ark.), now chairman of that committee, was in such a position and used it instead, first to block floor consideration of the House bill and then to hold up a conference agreement, until he had exacted two major concessions: a time limit on the President's authority to submit reorganization plans, and a veto by either chamber. $\mathrm{He}$ was unmoved either as a Democrat or as committee chairman by two formal messages from President Truman urging speedy passage. In retrospect it seems likely that the single-chamber veto, applicable to all plans, cost the executive more than it gained from the "clean bill" (without a list of exempted agencies) that the Commission set such store by.

In sum, the Commission succeeded in getting things moving and finding an area of agreement where conflict had prevailed. It generated more widespread favorable interest in the idea of reorganization than had been manifest before. Its reports led to extensive realignments of jurisdictions, and to a considerable strengthening of central institutions of direction and control. It made orthodox what had been rejected a decade earlier. But it did not escape political constraints, and its function was confirming rather than innovative.

\section{The Second Hoover Commission, 1953-1955}

If biptartisan composition and a balanced sharing of appointments were conditions necessary to the success of the first Hoover Commission, they were not sufficient, as the second commission showed. Constituted according to the same formula and having the same chairman, it nevertheless came to a very different end.

The election of President Eisenhower and the return of Republican majorities in both houses of Congress brought both a fresh impulse for reorganization proposals and apparently more propitious conditions for their favorable reception. His administration moved along two channels to that end. For immediate purposes the 1949 Act, then due to expire on April I, was quickly extended; and the President, by his first Executive Order, named an Advisory Committee on Government Organization (of which, more presently). For longer-range purposes two mixed commissions were created by law in July, 1953. A 25-member Commission on Intergovernmental Relations was to reconsider the distribution of functions between the national government and the states. A I2-member Commission on Organization of the Executive Branch was given the same terms of reference as the one of the same name six years earlier. These commissions symbolized the resurgence of the conservative sentiments that had partly motivated the previous endeavor. Their memberships, again carefully balanced in categories, spanned a fair spectrum of opinion, but a majority in each had chiefly ideological aims, to turn the clock back on federal activities and spending. The Eisenhower Administration appears to have turned the two commissions loose, with ample funds, to see where they could get.

Not far, in this instance. It would extend this account unduly to trace the hilarious record of the Commission on Intergovernmental Relations, which was a 
victim of the changing official climate as the new administration confronted and became committed on a series of concrete issues long before this Commission had its say in $1955 .{ }^{45}$ It wound up unable to agree on any single federal function it could recommend for abolition, and instead advocated the creation of one more piece of federal machinery, a monitoring staff in the Executive Office of the President to keep better track of evolving problems in federal-state relations.

The Second Hoover Commission reported in 1955 also, and fared no better. The Administration had sent up ten reorganization plans in 1953 and two more in 1954 and had seen them all sustained. Five of these, at least, raised significant issues: elevation of HEW to departmental status and authority for the Secretary of Agriculture over the internal structure of his department-both reversing previous defeats; further strengthening of the positions of the Secretary of Defense and Chairman of the Joint Chiefs; and reorganizations of the foreign aid and information agencies. Now came the Hoover report. The moderating internal constraints that had operated before were absent or diminished. Hoover either appeard to have learned little from the last round, or he took the occasion as a final opportunity, after many frustrations, to reach for his heart's desire. His task forces, liberated to comment on policy as well as on organization, did so freely. The Commission's report, too, indulged its chairman's well known policy views. Taking positions the Administration had passed by and could not endorse, it was read, perhaps with nostalgia, and firmly ignoredrelegated to discussion in professional journals. ${ }^{46}$ The near-blank record of reorganization plans submitted between I955 and 1960 -and not for want of Commission recommendations-is in the sharpest possible contrast with the outpourings in 1950 .

It would exaggerate the Commission's importance, however, and be unfair as well, to charge it with major responsibility for the paucity of reorganization plans during Eisenhower's second term. The combination of Democratic majorities in Congress again after 1954 and waning interest on the part of the Administration counted for more in the outcome. The point to be made here is not only that a public commission is no panacea, but that without a stance of neutrality toward substantive policies its labors are at the mercy of shifting political alignments on which it has little influence. By the time this one got organized and completed its work the suppositions on which it proceeded had evaporated.

\section{Presidential Task Forces}

A third general alternative to a congressional committee or a public commission as a means of conducting a reorganization survey and formulating specific proposals

\footnotetext{
${ }^{5}$ Commission on Intergovernmental Relations, Report (1955). All members signed the middleof-the-road report. But two footnotes, id. at 59-60, carrying between them the signatures of ten of the 25 members, deplored the Supreme Court's 1937 decision that sustained the constitutionality of the Social Security Act, and the liberalization of the spending power, as having "fundamentally altered the balance of power designed by the architects of the Constitution."

${ }^{40}$ See Fesler, Administrative Literature and the Second Hoover Commission Reports, $5 \mathrm{I}$ AMs. POL. SCr. REv. 135 (1957) for an acute critique.
} 
is a presidential task force. ${ }^{47}$ This course, whatever its disadvantages, tends to keep the reorganization ball in the President's court, so to speak, during the developmental stages of the process. From his standpoint it affords relative privacy, flexibility in adapting to changed conditions and control over both the content and timing of any published reports and recommendations. The first example of this type, though it does not closely resemble more recent models, was provided, as might be expected, by an activist President at odds with Congress, Theodore Roosevelt. It was entitled the Committee on Department Methods, and commonly known by the name of its chairman, Charles H. Keep, Assistant Secretary of the Treasury.

\section{The Keep Commission, 1905-1909}

President Roosevelt responded with characteristic enthusiasm to a proposal from Gifford Pinchot and James R. Garfield, members of his "tennis cabinet," for a study of the organization and operation of federal departments and agencies in Washington, with recommendations for their improvement. His letter of appointment, of June 2, I905, named these two and three others like-minded, all officials of subcabinet rank, and went on at some length with precepts for their guidance. ${ }^{48}$ The following year he asked the Congress for $\$ 25,000$ for the employment of experts to assist the Committee, and was grudgingly allowed $\$ 5,000$; the Committee later drew also on a $\$ 10,000$ confidential fund at the disposal of the Secretary of the Interior, which Garfield had meanwhile become. The Committee was one of half a dozen such that Roosevelt employed to get action by independent executive initiative in various fields. He told its members that "I shall value the reports I receive largely ... in proportion as they do not call for legislation." ${ }^{.49}$

The Committee formed and utilized a dozen subcommittees, coopting for that purpose some 70 other officials, to work on special topics within their ken. These ranged over a diverse array of subjects and dealt with methods, since the Committee perforce took jurisdictions as given. Only one of its reports eventuated directly, though later, in legislation: the creation of the General Supply Committee-an ancestor of the present General Services Administration-a permanent interdepartmental agency located in the Treasury, to standardize and contract for common supplies..$^{50}$

\footnotetext{
${ }^{\Delta 7}$ A fourth, not pertinent here to the institutionalization of the presidency, is a bureaucratic mission, such as the Bureau of Efficiency had, 19I6-r933, or as was given the General Accounting Office in the Legislative Reorganization Act of $1946, \S 206$, 6o Stat. 837 .

48 The most detailed account of the Committee and its work is by Kraines, The President versus Congress: The Keep Commission, 1905-1909, First Comprehensive Presidential Inquiry into Administration, 23 West. PoL. Q. 5 (1970). See also Pinkett, The Keep Commission, 1905-Igog: A Rooseveltian Effort for Administrative Reform, 52 J. AM. HIST. 299 (1965); WEBER, supra note 15, at 74-83; T. Roosevelt, An Autoblography 368 (r9I3); G. Pinchot, Breaking New Ground 296 (I947).

${ }^{10}$ Kraines, supra note 48 , at 35, quoting the New York Times of March 24, 1906. He also recommended to Congress that the President "be given power to transfer any part of the work of a department to another department." Id. But this would have required legislation which was not in the cards.

${ }^{\text {to }}$ Act of July 17 , I910, ch. $297, \S 4,36$ Stat. 531 .
} 
Two other proposals, for retirement allowances and position classifications and salary grades, marked early approaches to government-wide problems that would become subjects of legislation in the next generation-approaches that showed a considerable change in thinking about the treatment of government personnel from the harsh anti-employee attitudes plainly displayed in the Dockery-Cockrell studies. The Committee's expert on this subject, Herbert D. Brown, was thereby launched on a career with the Taft Commission, the Civil Service Commission and the Bureau of Efficiency, over the next two decades, as a leading authority on the improvement of administration; in those days the office of the chief executive provided no home for such a career.

Other subjects of the Committee's attention included the coordination of statistics, records management, government publications, accounting methods, transportation of government property and employees, interdepartmental telephone service, the need for an official gazette-realized in 1934 in the Federal Register-and the collection and publication of historical documents.

The Committee had scarcely gotten under way when the President handed it first one, and then, because he liked the Committee's handling of it, a second spot assignment of a quite different sort-to investigate a rumored bureaucratic scandal. The first involved the Public Printer and the award of a contract for typesetting machines; the second, the leaking and manipulation of cotton crop estimates to speculators. The Committee's inquiries and reports exposed the malefactors and their wrongdoings in these cases and so served the President's needs and brought public credit for the Committee as well, for its help in the housecleaning. But it seems doubtful that it could have continued in the capacity of an internal inspectorate and simultaneously have secured the cooperation at operating levels indispensable to its main function.

For the Committee aimed to make its impact on operations rather than on Congress or on public opinion. It prepared no overall report, and although $x 8$ of its individual reports were published in one form or another, many more were not. Its most notable accomplishment may have been the introduction of double-entry bookkeeping into the Treasury. But it is in the nature of its concern with administrative methods that the results it achieved presently became invisible.

The Keep Commission was a presidential instrument, responsive to Roosevelt's temperament and the political situation at the time. It lasted as long as he was in office and no longer; it left no institutional residue in the executive office beyond the precedent that a President found a way of asserting responsibility for improving the efficiency of operations in the executive branch. When he dealt with subcabinet officials directly, he risked undercutting the positions of department heads. And when he took the initiative himself he provoked congressional jealousy. On the last day of his term, Congress added a rider to an appropriation, proposed by Chairman James A. Tawney ( $R$., Minn.) of the House Appropriations Committee, aimed at the Keep Commission and others of that ilk. It forbade any future expendi- 
ture or detail of personnel "in connection with the work . . . of any commission, council, board, or other similar body, unless the creation of the same shall be or shall have been authorized by law. ..."

\section{The President's Advisory Committee on Government Organization, 1953, and Its Successors}

The post-World War II model of a presidential task force on reorganization was devised in the Eisenhower Administration and has commended itself, with modifications, to his successors. By his first Executive Order, President Eisenhower named an Advisory Committee on Government Organization consisting of Nelson A. Rockefeller, who had been active in the r952 campaign, Arthur S. Flemming, who had been the minority member of the Civil Service Commission, and Milton Eisenhower, the President's brother. The Committee used a report developed at Temple University ${ }^{52}$ and based on the Hoover Commission's unfinished agenda-President Robert $\mathrm{L}$. Johnson of Temple had been chairman of the Citizens' Committee for the Hoover Report-and it also was a clearing point for suggestions from cabinet members and other sources. In this fashion the machinery was set up for changes that could be accomplished by reorganization plans. ${ }^{53}$ The Committee worked to President Eisenhower's satisfaction during his first term and ran out of steam during his second.

President Kennedy turned to informal and, with one exception, unpublicized advisers for reorganization suggestions. The exception got him into one kind of trouble, and he took himself into another. Among the program planning projects undertaken during his r 960 campaign was a report by James M. Landis, former dean of the Harvard Law School and ex-chairman of the SEC, reviewing the problems of the independent regulatory commissions and their chronic backlogs. ${ }^{54}$ Kennedy thought so well of it that he publicly commended it to Congress before his inauguration, and it went also to the American Bar Association. It inspired seven reorganization plans that he sent up early in 1961, each dealing with one of the commissions and prescribing the same medicine, similar to the first Hoover Commission's: let the President designate the commission's chairman, to serve at his pleasure in that capacity; let the chairman's hand be strengthened within the commission; and carry further the delegation of authority to individual members, panels or staff to dispose of cases in the commission's name, subject to discretionary review by the whole commission.

The Landis report had gone further in urging that cordinating offices be established in the Executive Office of the President to develop government-wide policies

\footnotetext{
52 Act of March 4, 1909, ch. 299, §9, 35 Stat. I027.

E2 Afterward published as The Tempie Untverstty SuRvey of Federal Reorganization (I953).

${ }^{53} \mathrm{D}$. Eisenhowfer, MANDATE for Change 133-35 (1963).

- Senate Judictary SubcomamtTee on Administrattve Practice and Procendre, Report on Regulatory Agencies to the President-Elect, 86th Cong., 2d Sess. (Comm. Print 1960).
} 
for transportation, communications and energy, including relationships between the regulatory bodies and other agencies. Of the seven plans, only four were sustained. Those affecting the SEC, FCC, and NLRB, among the most politically sensitive of the regulatory agencies, were rejected. This outcome almost exactly paralleled President Truman's experience with his reorganization plans for the regulatory commissions in I950. The Brownlow Committee's proposal in this field had fared worse; it died aborning. But the point here is not that Kennedy's adviser did not save him from coming a cropper in a course where others had faltered before him. Rather it is that the publicity he had given the Landis report, so far from carrying the day, had only increased his discomfiture in the event.

Kennedy's other trouble came from submitting reorganization plans-notably Plan I of Ig62 to reverse a legislative defeat of the previous year and create a department of urban affairs-without showing them first to the Government Operations Committees. On this issue Senator McClellan held up the renewal of the Reorganization Act, when it expired in Ig63, for over a year. Even a personal communication to the senator from the new President, Lyndon Johnson, on the heels of his first annual message, followed up by a written assurance of consultation from the Budget Bureau, the bill stalled for four months. ${ }^{55}$ Consultation in advance is a perennial issue with far-reaching implications. Institutionalization of the process in this segment of policy, in the unlikely event it proved durable, would restrict the President more than the committee, since the initiative is his.

President Johnson improved on his two predecessors' reorganization records by sending up I7 plans in five years and seeing 16 of them sustained. In making his choices and formulating his strategy here, he kept entirely to informal and internal advice and unpublicized advisers-except when considering a single policy field only, as in the case of the postal reorganization proposed by the Kappel Commission. ${ }^{\text {.0 }}$ For a start on a comprehensive review he enlisted the help of a group headed by Dean Don K. Price of Harvard, along with technical staff work from the Budget Bureau, in $I 964$, in devising his agenda and strategy for using the rg6 renewal of the reorganization act. His most comprehensive effort was the establishment in November, I966, of a 7-man Task Force on Government Organization, to work altogether confidentially. It was headed by a private citizen, Ben W. Heineman, president of the Northwestern Railway, and included two officials, the Budget

\footnotetext{
${ }^{65}$ Acting Budget Director Elmer B. Staats on February 7, 1964, wrote carefully: "Please be assured of our intention to work closely with you and your committee concerning reorganization proposals and to take such other steps as may be necessary to improve communications between the executive branch and the Congress concerning reorganization plans. Through such cooperative efforts I am confident that it will be possible to eliminate or minimize the difficulties which you have identified." $S$. REP. No. I057, 88th Cong., 2d Sess. 3 (r964).

se Prestdent's Commission on Postal Organization, Towards Postal Excelience (1968). The essential problem for the President here was not what to do but how to stir enough support to overcome congressional and union opposition to a similar proposal made the previous year by his own Postmaster General, Lawrence F. O'Brien. New York Times, April 4, 1967, at 1, col. 1.
} 
Director and the Secretary of Defense, three ex-officials, McGeorge Bundy, Kermit Gordon, and William Capron, and one academic, Herbert Kaufman of Yale.

This aggregation of talent and experience produced private reports to the President by the latter part of the summer in Ig67 on some of the more intractable organizational problems-the coordination of anti-poverty programs and of economic policy, the future of HEW, the consolidation of regional administration, and others. But its work was largely aborted when the President decided not to run for reelection in I968. Since nothing was published, only the strategy was lost.

President Nixon, shortly after securing a two-year renewal of the Reorganization Act, took a less secretive course than Johnson's. His approach relied more on businessmen but was plainly within the confidential task force pattern. By a press release of April 5, 1969, he appointed five members to an Advisory Council on Executive Organization headed by Roy L. Ash, President of Litton Industries. The others were George Baker, soon to retire as Dean of the Graduate School of Business Administration at Harvard; ex-Governor of Texas John B. Connally; Frederick R. Kappel, head of A.T.\&T.; and Richard Paget, President of a well-known New York management consultant firm. A sixth was presently added, Walter N. Thayer, an investment banker and former proprietor of the New York Herald-Tribune. ${ }^{57}$ The Council was to "deal with both immediate and long-range needs for organizational changes to make the Executive Branch a more effective instrument of public policy." The announcement went on to say:

The Council will consider: (I) The organization of the Executive Branch as a whole in light of today's changing requirements of government; (2) Solutions to organizational problems which arise from among the 150 -plus departments, offices, agencies and other separate Executive organizational units; and (3) The organizational relationships of the federal government to states and cities in carrying out the many domestic programs in which the federal government is involved.

Although it is planned that staff assistance will be provided by the Budget Bureau's Office of Executive Management, the Council will have direct access to the President. Contacts with the Congress, the states and localities, and other interested entities will be handled through established government channels.

The Council will work closely with the Office of Intergovernmental Relations established by the President under the supervision of the Vice President to serve as the liaison between state and local governments and the President ... .58

The Council was given a budget of $\$ 930,000$ for fiscal 1970 and expected to complete its work by the end of that calendar year.

In less than 12 months the Council's first product was unveiled, in the form of

57 The Executive Director, Murray Comarow, who headed a staff of a score or more of professionals, had been with Booz, Allen and Hamilton, management consultants, and with the Federal Power Commission, and more recently the Executive Director of the Commission on Postal Organization appointed by President Johnson and chaired by Frederick Kappel.

${ }^{88}$ Office of the White House Press Secretary, Press Release, April 5, 1969. 
Reorganization Plan 2 of 1970 , which the President sent to Congress on March I2 and saw sustained by a bipartisan margin, 193 to 164 , in the House against an adverse committee recommendation. ${ }^{59}$ It established formally a cabinet-level Domestic Council and gave the Budget Bureau a boost in status by changing its name, creating some high-ranking positions in it and putting fresh emphasis on its managerial concerns-a boost the President reinforced by moving the Secretary of Labor, George P. Shultz, over to another cabinet seat as head of the Office of Management and Budget. The Ash Council also allowed press leaks to hoist trial balloons of reorganization proposals in other fields, including atomic energy, bank regulation, and the handling of environmental policies. As to the last of these, two more plans went up in July 1970, to create an independent Environmental Protection Agency with enforcement powers, and a National Oceanic and Atmospheric Administration with research missions, in the Commerce Department. But the Council made no general report and it remained within the President's discretion to decide what, if anything, to do with or about any of its recommendations to him. ${ }^{60}$ For example, in his next State of the Union message, January 22, x971 (after anticipatory soundings in the press a fortnight earlier), he drew on unpublished Council studies in proposing a sweeping consolidation of seven cabinet departments into four: Natural Resources, Human Resources, Community Development and Economic Development. The bold language of the message passed over the inconsistency of this appeal to hierarchy as a solution to problems of interdepartmental coordination with the Domestic Council solution adopted the previous year. But only three weeks after this seemingly quixotic gesture, the President cautiously released for "vigorous public discussion," without committing himself on it, a I25-page Ash Council report advocating the substitution of three single administrators for five of the regulatory commissions, with appeals from their decisions to a new 15-member administrative court. Although neither of these proposals was likely of enactment in I97r, the contrast in the methods of launching them was a vivid illustration of the options the President retained when the Ash Council disbanded.1.

The Council's existence and broad mandate did not preclude the appointment of other groups to consider reorganization in particular fields. Just as President Johnson had named the Kappel Commission to examine separately the touchy subject of renovating the Post Office, President Nixon set up the Fitzhugh Commission to review the organization of the Department of Defense, a perennial target. Its controversial report was made public. ${ }^{62}$

\footnotetext{
${ }^{69}$ See authorities cited in note 7 , stipra.

${ }^{60}$ In testimony on Plan 2, Chairman Ash explained, without specifying, that his Council started by identifying nearly "I00 organizational issues in the executive branch" and then gave priority to ten of these for detailed study. Hearings on Reorganization Plan No. 2 of 1970 Before the House Subcomtm. on Government Operations, 9xst Cong., 2d Sess. I5 (r970).

${ }^{61}$ N.Y. Times, Jan. II, I97x, at I, col. 5; Jan. 22, I97x, at I, col. 7; and Feb. 12, I97x, at I, col. 5.

${ }^{02}$ N.Y. Times, July 29, 1970, at 1 , col. 8.
} 
Conclusion

The foregoing review has distinguished three broad types of institutional approaches to comprehensive and official studies of executive branch reorganization, roughly associated with three overlapping time periods, and with basic shifts in the purpose and nature of the enterprise. Corresponding distinctions in institutionalization of the processes can be marked out.

In the first phase, lasting a half a century, the main purported object of the endeavor was "economy," to be realized chiefly by modernization of office methods; and the principal stakes were patronage. A further means of advancing the same general object was thought to be the elimination of "overlapping and duplication," by bringing together similar activities previously dispersed. The issue in this phase turned on the congressional claim-grounded in the second doctrine of $x 789-$ of a monopoly prerogative over any decision, not only to change the organization of the executive branch, but even to undertake to study what changes might be desirable. This was the claim asserted in the Tawney Amendment, and rejected both by Theodore Roosevelt when he set up the Keep Commission and by Taft when he sought authorization for the Commission on Economy and Efficiency. The paradoxical observation that the President was more interested in legislation, while the Congress was more interested in administration, was made by Senator Jonathan P. Dolliver (R., Iowa) in opposing the creation of the Taft Commission:

We have fallen upon times new and strange, when the frame, as well as the details, of legislation is perfected in the executive departments, and it looks as though this proposal for a commission were either an act of reciprocity or retaliation ... by which Congress is about to say to the executive departments: "You attend to the preparation of bills for the Congress of the United States, and we will, as soon as possible, try to institute a modern system of bookkeeping for you.", 33

The congressional claim of monopoly rights in the search for economy was finally and formally abandoned in Section I of the Reorganization Act of $x 939$, which conferred on the President a permanent license to study the subject, with the help of the Budget Bureau. Partly, this may be attributed to the relative secular decline in the stakes of patronage. More directly, it was probably a result of the emergence of central managerial instruments-in the departments, and government-widebetter adapted to the purpose of effectuating detailed economies. The task had far outrun the capacities of either the President or Congress; it was delegated to administrative hands and the processes were pretty fully institutionalized there-saving a congressional prerogative for selective intervention.

The second approach, the resort to public commissions on reorganization be-

\footnotetext{
${ }^{88} 45$ Cong. Rec. 2159-60 (rgro). Cf. Huntington, Congressional Responses to the Twentieth Century, in Congress and America's Future 22-25 (D. Truman ed. 1965); G. Gariowat, The Legistative Process in Congress $x 66$ (1955).
} 
tween I9Io and 1955 , failed to become institutionalized as a method of proceeding except when limited to specific policy fields. The circumstances of their creation differed markedly in each of the four instances reviewed here: they were ad hoc phenomena that set no pattern. Three of the four were done in by changed political alignments before their work was done. Except for the Brownlow Committee, it took them a couple of years to produce. The establishment of such a commission commits the Administration to try to take its work seriously; some prestige is lost if the effort comes to nothing. The relative detachment of a commission should enable it to speak bluntly and critically about offices and incumbents too close to the President for him to deal with candidly. The Taft and Brownlow commissions were redeemed by the educational value of the innovations they proposed, the fresh perspectives they introduced, which ultimately brought practical results. But these merits have not outweighed their risks in the eyes of presidents since the I950's. Senator Abraham Ribicoff (D., Conn.), chairman of a Government Operations subcommittee, secured Senate passage in $\mathrm{rg68}$, a campaign year, of a bill to establish a commission on the Hoover model. But the Budget Bureau opposed it and the House buried it. ${ }^{84}$ It seems unlikely that a President will sponsor such a measure in the foreseeable future unless he is in deep trouble on other scores.

The relatively unpublicized task force method adopted by four successive Presidents since Truman is a logical outgrowth of the transformation in reorganization objectives that had already taken place. The Brownlow report in 1937 proclaimed that change in doctrine, from economy in operations to the need for strengthening the President's capacity to marshall and wield the far-flung resources of the executive branch. The first Hoover Commission gave this doctrine wider currency and greater legitimacy. It is a corollary, consonant with the first doctrine of 1789 , that the President is entitled to avail himself of that method of formulating reorganization proposals which promises him the greatest degree of control over their form, content, and timing, since he has the most at stake.

It might be supposed that the principal beneficiary of a doctrine of presidential primacy would be the Budget Bureau and, accordingly, that the reorganization process would become as institutionalized as the formulation of the budget. The Bureau has had the legal authority for many years; it has had able people and has accumulated expertise. The technical intricacies of reorganizations-the legal niceties, the procedural precedents and case-law, the substantive disposition of funds, obligations, personnel, and so on-now comprise a formidable body of specialized knowledge, indispensable in making plans operational. The Bureau commands that knowledge. It also serves what it understands to be the interests of the presidency, and serves the incumbent President too, if it gets timely clues to his wishes. The Nixon Administration, in reconstituting the Office of Management and Budget, has

\footnotetext{
"see Hearings on a Bill to Establish a Commission on the Organixation and Management of the Executive Branch Before the Subcomm. on Executive Reorgatization of the Senate Comm. on Government Operations, goth Cong., 2d Sess. (1968).
} 
apparently tried to build a bureaucratic capability there that might make the task force device unnecessary in the future.

On the record since I92x, however, there are serious obstacles in the way of full reliance on that resource: the Bureau has been starved for appropriations itself; the interest of Presidents has been fluctuating and spasmodic; the Bureau's staff cannot very well reach up unless the President reaches down. ${ }^{65}$ The virtue of the task force method is its flexibility in compensating for these handicaps and responding to the President's political assessments. The extent of the President's resort to that method is a measure of the limits he feels, or imposes, on the institutionalization of the process.

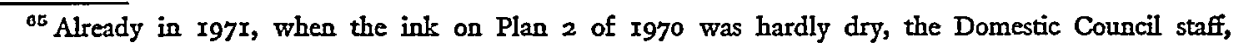
reporting to its chairman, presidential assistant John Ehrlichman, had formed a subcommittee on organizational problems. It worked, at first unbeknownst to the Office of Management and Budget organizational staff, on, among other things, measures to give effect to the President's proposal to establish four superdepartments. 